\title{
Correspondence
}

https://doi.org/10.11646/phytotaxa.334.1.11

\section{Massonia visseriae (Asparagaceae, Scilloideae): rediscovery of a neglected species of Neobakeria and its transfer to Massonia}

\author{
MARIO MARTÍNEZ-AZORÍN ${ }^{1 *}$, MICHAEL PINTER ${ }^{2}$, MANUEL B. CRESPO ${ }^{1}$, MARÍA ÁNGELES ALONSO- \\ VARGAS $^{1} \&$ WOLFGANG WETSCHNIG ${ }^{2}$ \\ ${ }^{I}$ dCARN (Depto. Ciencias Ambientales y Recursos Naturales) \& CIBIO (Instituto Universitario de la Biodiversidad), Universidad de \\ Alicante, P. O. Box99,E-03080 Alicante,Spain.e-mail: mmartinez@ua.es \\ ${ }^{2}$ Institute of Plant Sciences, NAWI Graz, Karl-Franzens-University Graz, Holteigasse 6, A-8010, Graz, Austria. \\ *author for correspondence
}

Asparagaceae subfamily Scilloideae, tribe Hyacintheae is alternatively regarded as Hyacinthaceae subfam. Hyacinthoideae. Additional information on generic circumscriptions in Hyacinthoideae can be found in Martínez-Azorín et al. (2013, 2014a, 2014b), Pinter et al. (2013) and Wetschnig et al. (2014).

The genus Massonia Houttuyn (1780: 424) belongs to tribe Massonieae of Hyacinthoideae (Speta 1998a, 1998b, Wetschnig et al. 2002, Pfosser et al. 2003, Manning et al. 2004) confined to South Africa and southwestern Namibia. Our studies in Massonia reveal that the taxonomy of the genus, as presented in recent revisions, is not satisfactory and several species concepts have been either overlooked or misunderstood (Wetschnig et al. 2012, 2014, Martínez-Azorín et al. 2013, 2014a, 2014b, 2015a, 2015b, 2017, Pinter et al. 2013, 2015).

Neobakeria Schlechter (1924: 149) was characterized as having uniseriate filaments which are distinctly connate above the perigone, and included 7 species placed by Baker in Polyxena Kunth (1843: 294) subgenus Astemma Baker (1897: 419) such as Neobakeria angustifolia (Linnaeus 1782: 193) Schlechter (1924: 150); N. burchellii (Baker 1897: 420) Schlechter (1924: 150); N. comata (Baker 1897: 419) Schlechter (1924: 150); N. haemanthoides (Baker 1888: 1727) Schlechter (1924: 150); N. marginata (Baker 1897: 420) Schlechter (1924: 150); N. namaquensis Schlechter (1924: 150) and N. rugulosa (Baker 1897: 420) Schlechter (1924: 150), N. namaquensis being the type (Müller-Doblies \& Müller-Doblies 1997). Two additional species were later described in this genus, as Neobakeria heterandra Isaac (1939: 729) and N. visseriae Barnes (1933: 72).

All Neobakeria species are currently placed in Massonia or in Daubenya Lindley (1835: t. 1813), except Neobakeria visseriae. Schlechter (1924) related his new genus Neobakeria to Polyxena and Massonia, but he differenced Polyxena by the biseriate and almost free filaments above the perigone and Massonia by the uniseriate filaments only shortly connate above perigone (Schlechter 1924). The generic circumscription within tribe Massonieae has strongly changed in the last decades (Müller-Doblies \& Müller-Doblies 1997, Manning \& van der Merwe 2002), but at present it seems to exist a consensus on placing the Neobakeria species in Massonia or Daubenya depending on their bulb, leaves, inflorescence, and bract morphology (Manning \& van der Merwe 2002). Our ongoing taxonomic and phylogenetic studies revealed that Massonia includes species with nearly free filaments above the perigone to distinctly connate to form a filaments tube, not supporting recognition of Schlechter's Neobakeria.

Neobakeria visseriae was described from plants collected "on a Klip Koppie about 5 miles from Lambert's Bay" by H.A. Visser in May 1931. The protologue describes the plants as having dark green leaves with longitudinal striation and elongated pustules that bear fascicles of white trichomes; flowers white with a cylindrical perigone tube, not expanded at the apex; filaments ca. $6 \mathrm{~mm}$ long and connate to form a tube ca. $1.5 \mathrm{~mm}$ long above the perigone; and a pale green ovary with a cylindrical style shorter than the stamens. The holotype is kept at BOL and includes 5-6 plants, 4 of them in flower, and a detailed drawing of the plant, made by P.E. Barnes. Both the pressed plants and the drawing perfectly agree with the protologue, however we can highlight some further additional characters from the illustration, such as the free perigone segments being spreading, but neither strongly reflexed nor with a sigmoid inrolled curve, and the fascicles of unequal trichomes on elongated leaf emergences. Furthermore, although the illustration shows filaments of similar length, the flowers inside the envelope in the holotype specimen show unequal filaments and blue anthers with blue pollen.

After several failed trials to find this species in nature around Lambert's Bay, we found one population of Massonia visseriae at the type locality, on a Klip Koppie near Jakkalsrivier ca. 6 km E of Lambert's Bay between Van Putensvlei and Groendam farms. Our phylogenetic analyses (not shown) confirm the inclusion of this species in Massonia, also supported 
by morphology. Therefore, we propose a new combination in Massonia for Neobakeria visseriae. A complete morphological description is presented below based on the study of living material, and comments on its ecology and distribution are reported.

\section{Materials and Methods}

Detailed morphological studies of Massonia were undertaken on natural populations, cultivated specimens and herbarium vouchers, as elaborated upon in Martínez-Azorín et al. $(2007,2009)$. Herbarium specimens from the herbaria ABH, B, BLFU, BM, BOL, E, G, GZU, GRA, HAL, K, L, LINN, M, MO, NBG, NU, NY, P, PRE, S, TCD, UPS, W, WU, Z, ZSS, and ZT (acronyms according to Thiers 2017) were studied. Orthography of geographical names and grid-number system follow Leistner \& Morris (1976).

\section{A new combination in Massonia}

Massonia visseriae (P.E.Barnes) Mart.-Azorín, M.Pinter, M.B.Crespo, M.A.Alonso \& Wetschnig comb. nov. Basionym:-Neobakeria visseriae Barnes (1933: 72). Fig. 1.

Type:-SOUTH AFRICA. Western Cape. Clanwilliam (3218): On a Klip Koppie ca. 5 miles from Lambert's Bay, Clanwilliam Div. (-AB), May 1931 [in flower], H.A. Visser sub BOL19616 (holotype BOL140472!, available at http://plants.jstor.org/stable/viewer/10.5555/ al.ap.specimen.bol140472). Note:-A herbarium collection at Kew (K000257133) is identified in pencil as isotype of Neobakeria visseriae. It was collected near Lambert's Bay by Visser sub BOL19616, and Visser wrote in the label that leaves are minutely scabrous, what would fit in general terms with the protologue of $N$. visseriae. The study of this collection, however, evidences the necessity to exclude it from the type material of $N$. visseriae, as the collection was named by Visser herself as "Massonia latifolia?" and was collected in July 1932. Furthermore, the plant in the voucher shows a much larger size and some floral characters not fitting the protologue, it indeed belonging to the Massonia depressa aggregate. Therefore, the collection at Kew should be disregarded as original material.

Description based on living material:-Deciduous geophyte. Bulb ovoid to subglobose, 1.5-3 $\times 1-3.5 \mathrm{~cm}$, with white, fleshy bulb scales covered by pale brown, papery outer tunics. Leaves 2 , synanthous, opposite, appressed to the ground, ovoid to lanceolate, longitudinally striate, with a very short apicule at the apex, limb 3-14 $\times 2.5-8 \mathrm{~cm}$, with narrow, membranous, minutely papillose margins; adaxial side green, with 0-50 elongated emergences per $\mathrm{cm}^{2}$, up to $2 \mathrm{~mm}$ in length, with fascicles of unequally elongated and narrowly conical trichomes, $0.2-1 \mathrm{~mm}$ long; abaxial side smooth, green; petiole $1-5 \mathrm{~cm}$ long. Inflorescence a dense, subcapitate raceme, up to $2-4 \mathrm{~cm}$ long with up to 50 flowers, shortly overtopping ground level. Bracts narrowly obovate-lanceolate, attenuate at the apex, $12-14 \times 3-5 \mathrm{~mm}$, green in the upper half with white entire membranous margins and base, glabrous, minutely papillate on margins. Pedicels at anthesis 10-13 mm long. Flowers pentacyclic, trimerous. Perigone long and narrowly tubular, not distinctly widening at the end of the tube formed by 6 white tepals; free segments $6-7 \times 1-1.5 \mathrm{~mm}$, entire, white, straight and erect in bud, spreading to slightly reflexed at anthesis, neither inrolled nor with a distinct sigmoid curve at the base; perigone-filaments tube $14-17 \times 1.5-2 \mathrm{~mm}$, narrowly cylindrical, not widening in the upper portion, with the mouth showing strongly convex sides, giving the appearance of having 6 gibbosities, the ovary deeply included in the tube. Stamens 6 . Filaments white, long-attenuate, $9-12 \mathrm{~mm}$ long, spreading at anthesis and unequal in length, the outers being longer, distinctly connate at the base for 2-3 $\mathrm{mm}$ above the perigone segments; anthers oblong, dark blue, $1.2-1.6 \times 0.4-0.6 \mathrm{~mm}$ when closed, dorsifixed, with blue pollen. Gynoecium tricapelar, syncarpic, obclavate. Ovary conical to suboblong, pale green to yellow, 3-4 $\times 1-1.2 \mathrm{~mm}$, gradually tapering to the style. Style white, gradually tapering into the apex, erect, $12-17 \mathrm{~mm}$ long at anthesis. Capsule ovate in lateral view, trigonous with blunt edges in apical view, ca. 6-8 $\times 4-6 \mathrm{~mm}$. Seeds globose, black, ca. $1.8 \times 1.5 \mathrm{~mm}$, smooth.

Eponymy:- The specific epithet (visseriae) honours the collector of the type material, Miss H.A. Visser.

Phenology:-Massonia visseriae mostly flowers in May and June in the wild.

Habitat:-Massonia visseriae is found in rock pockets with shallow sandy soil in rocky outcrops; the surrounding vegetation is classified as Leipoldtville Sand Fynbos (FFd2); the region is characterised by winter rainfall peaking from May to August, with a mean annual precipitation of $260 \mathrm{~mm}$ and 3-4 days of frost per year (Mucina \& Rutherford 2006).

Distribution:- This species is known to us only from a single population in the surroundings of Lambert's Bay. Although it seems to be a rare species, only collected twice after the original description, further studies are needed to evaluate its conservation status and distribution. 

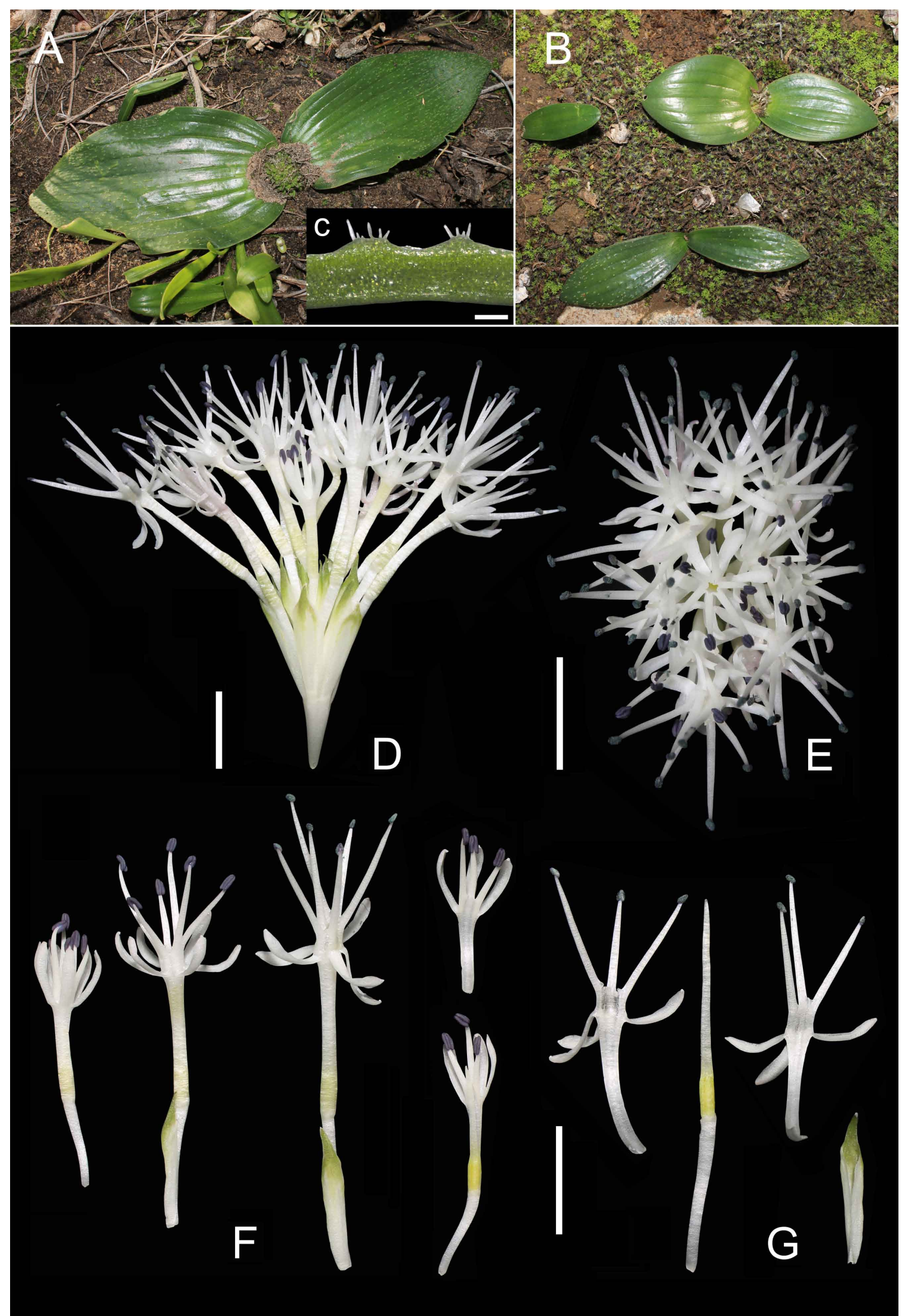

FIGURE 1. Massonia visseriae (P.E.Barnes) Mart.-Azorín et al. in habitat E of Lambert's Bay (type locality) on 23 July 2016 (A, B) and in cultivation from the type locality grown at the University of Alicante on 25 October 2017 (C-G). A. Plant in fruit showing longitudinally striate leaves with elongated pustules with trichomes; B. Plants with smooth and pustulate leaves cooccuring; C. Elongated emergences with trichomes of different lengths; D. Inflorescence, lateral view; E. Inflorescence, apical view; F. Flowers, lateral view; G. Dissected flowers, lateral view. Scale bars, C: $0.5 \mathrm{~mm}$; D-G: $1 \mathrm{~cm}$. 
Taxonomic relationships:-Massonia visseriae shows a combination of morphological characters that facilitates its recognition as a distinct species. The leaves with elongated pustules bearing fascicles of unequal trichomes (sometimes plants with smooth glabrous leaves occur in the same population); the flowers with narrowly cylindrical perigone-filaments tube, not widening at the apex and with six gibbosities at the mouth of the tube; the spreading perigone segments; the unequal filaments that are distinctly connate above the perigone; the blue anthers and pollen; and the obclavate gynoecium with the style shortly overtopping the perigone filaments-tube, allow clear distinction of the species.

Massonia heterandra (Isaac 1939: 729) Jessop (1976: 426) resembles M. visseriae regarding the unequal length of the stamens and the pustulate leaves, but the former differs by the isodiametric emergences with short trichomes on top, perigone-filaments tube only about $8 \mathrm{~mm}$ long, the filaments connate above the perigone for less than $1 \mathrm{~mm}$, the style clearly exceeding the perigone-filaments tube and the usually pinkish colour of flowers and gynoecium, among other characters. Furthermore, M. heterandra occurs at high elevations in the SW Cape Mountains.

Massonia pseudoechinata Mart.-Azorín, M.Pinter \& Wetschnig in Martínez-Azorín et al. (2015b: 124) differs from M. visseriae by the leaves with scarce to numerous small isodiametric emergences with a declinate, smooth trichome; larger bracts; longer flower pedicels; flowers with strongly reflexed and inrolled perigone segments bearing a distinct sigmoid curve at the base; filaments shortly connate above perigone; and larger capsules (Martínez-Azorín et al. 2015b). Other species such as M. bakeriana Pinter et al. (2015: 52), M. dentata Martínez-Azorín et al. (2014a: 203), M. roggeveldensis Mart.-Azorín et al. (2015b: 122), or M. tenella Sol. ex Baker (1870: 389) differ from M. visseriae by a distinct combination of characters (Baker 1870; Pinter et al. 2015; Martínez-Azorín et al. 2014a, 2015b).

Additional specimens studied:-SOUTH AFRICA. Western Cape. Clanwilliam (3218): Lambert's Bay (-AB), Clanwilliam C.P., 13 May 1963, H. Hall s.n. (NBG76417!); Clanwilliam (3218): ca. 4.5 km E of Lambert's Bay, on gravel road to Vredendal (-AB), $32 \mathrm{~m}$ elev., shallow sandy soils on rock ledges and crevices, 23 July 2016, M. Martínez-Azorín, M.B. Crespo, M.A. Alonso, J.L. Villar, A. Vicente, J. Moreno \& A. Terrones MMA1480 (ABH74263!, GRA!).

\section{Acknowledgements}

This work was partly supported by H2020 Research and Innovation Staff Exchange Programme of the European Commission, project 645636: 'Insect-plant relationships: insights into biodiversity and new applications' (FlyHigh) and University of Alicante (Spain). CapeNature of Western Cape Province provided permission to collect herbarium specimens (collecting permits numbers AAA008-00031-0028 and 0028-AAA008-00203). We acknowledge the help of all herbaria curators who kindly provided material and information and J.L. Villar, A. Vicente, J. Moreno and A. Terrones for their assitance in the field. We also would like to thank all the numerous garden and plant enthusiasts who publish valuable information and images on plants on the internet and who contribute substantially to the increase of knowledge.

\section{References}

Baker, J.G. (1870) A revision of the genera and species of herbaceous capsular gamophyllous Liliaceae. Journal of the Linnean Society. Botany 11: 349-436.

Baker, J.G. (1888) Polyxena haemanthoides. Hooker's Icones Plantarum 18: t. 1727.

Baker, J.G. (1897) Liliaceae. In: Thiselton-Dyer, W.T. (Ed.) Flora Capensis 6. Reeve and Co., London, pp. 253-525.

Barnes, P.E. (1933) Novitates africanae. Journal of Botany, British and Foreign. London 71: 69-73.

Houttuyn, M. (1780) Natuurlijke Historie of uitvoerige Beschryving der Dieren, Planten en Mineraalen, volgens het Samenstel van der Heer Linnaeus II, 12, Amsterdam, 558 pp.

Isaac, F.M. (1939) Neobakeria heterandra. Flowering plants of South Africa 19: 729.

Jessop, J.P. (1976) Studies in the bulbous Liliaceae in South Africa 6. The taxonomy of Massonia and allied genera. Journal of South African Botany 42: 401-437.

Kunth, C.S. (1843) Enumeratio Plantarum 4. Cottae, J.G., Stuttgarttiae et Tubingae, 752 pp.

Leistner, O.A. \& Morris, J.W. (1976) Southern African Place Names. Annals of the Cape Provincial Museum 12: 1-565.

Lindley, J. (1835) Daubenya aurea. Edwards's Botanical Register 21: t. 1813.

Linnaeus, C. (1782) Supplementum plantarum systematis vegetabilium. Orphantrophius, Braunschweig, 467 pp.

Manning, J.C. \& Van der Merwe, A.M. (2002) Systematics of the genus Daubenya (Hyacinthaceae: Massonieae). Bothalia 32: $133-150$.

Manning, J.C., Goldblatt, P. \& Fay, M.F. (2004) A revised generic synopsis of Hyacinthaceae in Sub-Saharan Africa, based on molecular evidence, including new combinations and the new tribe Pseudoprospereae. Edinburgh Journal of Botany 60: 533-568. 
Martínez-Azorín, M., Crespo, M.B. \& Juan, A. (2007) Taxonomic revision of Ornithogalum subg. Cathissa (Salisb.) Baker (Hyacinthaceae). Anales del Jardin Botánico de Madrid 64: 7-25.

http://dx.doi.org/10.3989/ajbm.2007.v64.i1.47

Martínez-Azorín, M., Crespo, M.B. \& Juan, A. (2009) Taxonomic revision of Ornithogalum subg. Beryllis (Hyacinthaceae) in the Iberian Peninsula and the Balearic Islands. Belgian Journal of Botany 142: 140-162.

Martínez-Azorín, M., Pinter, M., Crespo, M.B., Pfosser, M. \& Wetschnig, W. (2013) Massonia mimetica (Hyacinthaceae, Hyacinthoideae), a new remarkable species from South Africa. Stapfia 99: 187-197.

Martínez-Azorín, M., Clark, V.R., Pinter, M., Dold, A.P., Crespo, M.B., Barker, N.P., Pfosser, M. \& Wetschnig, W. (2014a) Massonia dentata (Asparagaceae, Scilloideae), a new species from the Nuweveldberge, southern Great Escarpment, South Africa and typification of M. calvata. Phytotaxa 175: 201-215.

http://dx.doi.org/10.11646/phytotaxa.175.4.2

Martínez-Azorín, M., Pinter, M., Deutsch, G., Brudermann, A., Dold, A.P., Crespo, M.B., Pfosser, M. \& Wetschnig, W. (2014b) Massonia amoena (Asparagaceae, Scilloideae), a striking new species from the Eastern Cape, South Africa. Phytotaxa 181: 121-137. http://dx.doi.org/10.11646/phytotaxa.181.3.1

Martínez-Azorín, M., Dold, A.P., Pinter, M., Slade, J., Crespo, M.B., Milkuhn, G. \& Wetschnig, W. (2015a) Massonia obermeyerae (Asparagaceae, Scilloideae), a new species from South Africa. Phytotaxa 205: 39-50.

http://dx.doi.org/10.11646/phytotaxa.205.1.3

Martínez-Azorín, M., Pinter, M., Crespo, M.B., Slade, J, Deutsch, G. \& Wetschnig, W. (2015b) Clarification of Massonia echinata and some other frequently misunderstood Massonia species (Asparagaceae, Scilloideae), with the description of M. pseudoechinata and M. roggeveldensis. Phytotaxa 239: 101-129. http://dx.doi.org/10.11646/phytotaxa.239.2.1

Martínez-Azorín, M., Pinter, M., Crespo, M.B., Alonso-Vargas, M.A. \& Wetschnig, W. (2017) Massonia gypsicola (Asparagaceae, Scilloideae), a new species from the Knersvlakte in South Africa. Phytotaxa 308: 144-150. https://doi.org/10.11646/phytotaxa.308.1.16

Mucina, L. \& Rutherford, M.C. (Eds.) (2006) The Vegetation of South Africa, Lesotho and Swaziland. Strelitzia 19. South African National Biodiversity Institute, Pretoria, $807 \mathrm{pp}$.

Müller-Doblies, U. \& Müller-Doblies, D. (1997) A partial revision of the tribe Massonieae (Hyacinthaceae). Feddes Repertorium 108: 49-96. http://dx.doi.org/10.1002/fedr.19971080106

Pfosser, M., Wetschnig, W., Ungar, S. \& Prenner, G. (2003) Phylogenetic relationships among genera of Massonieae (Hyacinthaceae) inferred from plastid DNA and seed morphology. Journal of Plant Research 116: 115-132.

Pinter, M., Brudermann, A., Crespo, M.B., Deutsch, G., Martínez-Azorín, M., Müller-Doblies, U., Müller-Doblies, D., Pfosser, M. \& Wetschnig, W. (2013) Massonia citrina (Hyacinthaceae, Hyacinthoideae) - a new species from the Western Cape Province (South Africa). Phytotaxa 112: 50-56.

http://dx.doi.org/10.11646/phytotaxa.112.2.3

Pinter, M., Martínez-Azorín, M., Crespo, M.B. \& Wetschnig, W. (2015) Massonia bakeriana (Asparagaceae, Scilloideae), a new pustulate species from the Northern Cape Province (South Africa). Phytotaxa 222: 51-60.

http://dx.doi.org/10.11646/phytotaxa.222.1.5

Schlechter, R. (1924) Drei neue Gattungen der Liliaceen aus Südafrika. Notizblatt des Botanischen Gartens und Museums zu BerlinDahlem 9: 145-151.

Speta, F. (1998a) Hyacinthaceae. In: Kubitzki, K. (ed.) The families and genera of vascular plants 3. Springer, Berlin, pp. $261-285$.

Speta, F. (1998b) Systematische Analyse der Gattung Scilla L. s.l. (Hyacinthaceae). Phyton (Horn) 38: 1-141.

Thiers, B. (2017) Index Herbariorum: A global directory of public herbaria and associated staff. New York Botanical Garden's Virtual Herbarium. Available from: http://sweetgum.nybg.org/ih/ (accessed November 2017)

Wetschnig, W., Pfosser, M. \& Prenner, G. (2002) Zur Samenmorphologie der Massonieae Baker 1871 (Hyacinthaceae) im Lichte phylogenetisch interpretierter molekularer Befunde. Stapfia 80: 349-379.

Wetschnig, W., Brudermann, A., Knirsch, W., Pinter, M. \& Pfosser, M. (2012) Massonia pustulata Jacq. 1791 and M. longipes Baker 1897 (Hyacinthaceae), two frequently misunderstood species - or how M. pustulata became depressed. Stapfia 97: $210-221$.

Wetschnig, W., Martínez-Azorín, M., Pinter, M., Brudermann, A., Deutsch, G., Crespo, M.B., Dold, A.P. \& Pfosser, M. (2014) Massonia saniensis (Asparagaceae, Scilloideae), a new species from Lesotho. Phytotaxa 173: 181-195.

http://dx.doi.org/10.11646/phytotaxa.173.3.1 